\title{
Youth Eco Activism in Slovakia: Case of Wolf - Forest Protection Movement
}

\author{
RADOSLAV HLÚŠEK
}

\author{
Department of Ethnology and World Studies, \\ University of SS. Cyril and Methodius in Trnava \\ radoslav.hlusek@ucm.sk
}

\begin{abstract}
The study deals with the activism of young Slovak people on the field of ecology and conservation of Slovak nature. As an example of this kind of activism Wolf - Forest Protection Movement was selected because it is the most active and most successful environmental organization in Slovakia. The main objective of this case study is to describe and analyse organisational structure and activities of Wolf on the background of wider general and theoretical framework what enables to classify this organisation in wide spectrum of youth activism, especially youth environmental activism in Slovakia. Apart from theoretical approach, organisational structure and broad range of activities of Wolf the study presents also political and civic attitudes of its young members, financing of the organisation and attractiveness of Wolf to young people in Slovakia.
\end{abstract}

KEY WORDS: youth, activism, conservation, environment, Slovakia, Wolf

\section{Introduction}

The study of social movements has given rise to several issues, one of which is how to classify these movements. I am aware of the multitude of options available for this purpose and I do not intend to question the commonly known fact that classifications can be based on different criteria and different social science approaches. But exactly because of this multitude, I had to decide on one criterion that would allow me to categorize the particular movement I was studying within the framework of my research as a part of MYPLACE 
project ${ }^{1}$. For the purpose of this case study I classified the selected movement according to the main objective of its activity and its methods of achieving this objective.

Wolf - Forest Protection Movement as selected case is an environmentalist and conservationist organisation (not social, political, or nationalist, etc.) focused on the conservation of so-called evolutional forests (natural ones, we could say virgin forests) in Slovakia as a way to protect the country from floods and droughts, and on keeping these forests untouched, without interference from foresters and hunters.

Somewhere here it is possible to examine why this particular movement was selected as a case study. There are numerous environmental organisations in Slovakia and across Europe, and many Europeans are concerned about the ecological problems of their motherlands or of the Earth in general. The popularity of and support for the Greenpeace organisation in the worldwide context is notable. Greenpeace has a branch in Slovakia, but I did not choose to study it because it deals with global environmental problems and is too huge as an organisation to be useful for the purposes of the project. And, last but not least, it is not an organisation of Slovak origin. In contrast to Greenpeace, Wolf deals with specific national environmental issues and does not concern itself with global ones. It believes that trying to solve global problems would make it to too generalized and too far removed from Slovakia's real problems.

Again, there are several environmental organisations in Slovakia, and so the question of why Wolf was chosen over the others is legitimate. At first, I intended to research the Slovak Association of Conservationists of Nature and the Land (Slovenský zväz ochrancov prírody a krajiny - SZOPK). It has been in existence since long before the fall of the communist regime in 1989, and it served as an umbrella organisation for Slovak conservationists. I was a member of SZOPK as a schoolboy in the 1980s, so I wanted to know what it was doing now. But I discovered that this organisation had deteriorated over the last two decades, with almost no young people currently among its members. Slovakia has other groups dealing with ecological lifestyles or environmental pollution, but they are not as well known among the Slovak public for their civic and legislative activities as Wolf is.

\footnotetext{
Memory, Youth, Political Legacy And Civic Engagement (MYPLACE) is the project which was running from 2011 to 2015. It was aimed at civic engagement of the youth, and also at collective memory, and its transmission among the young people, and their families. To see more consult http://www.fp7-myplace.eu.
}

DOI: $10.1515 /$ eas-2015-0010

(c) University of SS. Cyril and Methodius in Trnava. All rights reserved. 
In approaching the organisation, the initial research questions remained open. Little was known about Wolf as an organisation or its campaigning activities, and so the initial task was to learn as much about Wolf as possible. This meant beginning by studying the movement as a whole, considering its organisational structure, the number of members, their age and gender, and its campaigning and practical activities. It was only after this information had been gathered that was further data sought on the young members of Wolf, their position within the movement and their levels of engagement and activism. Much of this second goal was accomplished during the period of research for this case study and yet there is still much to learn. Thus, research with Wolf continues on an open-ended basis.

Researchers in the field of youth activism across Europe do not often dedicate themselves to the study of environmental activism. The overwhelming majority of scientific papers and monographs deal with social and political movements, with special attention to nationalist groups, especially extremist ones, which are mostly right-wing. However, since environmental movements form part of a broader set of civil and social movements, and civic and social movements form part of a civil society, it is useful to follow the approach of social movement theory as outlined by Pickvance. She believes that only a civil society can produce fully developed social movements, which she defines as protests and civil activities which seek to limit power rather than to gain it (PICKVANCE 1997:49). This definition can be applied to the Slovak context, and the activism of Wolf is an illustrative example. And even though Wolf is not considered here to be a social movement in the strictest sense, it is possible to agree with another of Pickvance's definitions, related this time to social movements, which claims that social movements are partially institutionalized collective activities which have a structure but, unlike political parties, do not require membership. Further, instead of discipline, solidarity and dedication are expected from movement participants (PICKVANCE 1997:35-36). If the word 'social' were exchanged for 'civic' the result would be a more proper definition, giving a truer picture of Wolf.

Zani and Cicognani have outlined the problem of the so-called 'Disengaged Generation', arguing that the younger generations of today are distant from politics and less engaged in comparison both with older age groups and older generations at the same young age. However, they also observe that the decrease in political participation has been accompanied by an increase in voluntary civic and social activities and new forms of activism (ZANI and CICOGNANI 2010:83). The young members of Wolf cannot be included in the Disengaged Generation, but it is true that the majority of Slovak youth are so disappointed by the politics and the current social and political situation in the country that they have lost interest in public affairs. As members of the organisation, the youngsters involved in Wolf are strictly apolitical and do not organise or participate in political events. 
However, through their civic engagement, they confirm the second part of Zani and Cicognani's statement. Volunteerism is a significant and typical attribute of Wolf. Although the organisation has a few paid employees, these employees are not young, and Wolf would not be as successful as it is without volunteers.

The approach of the theory of subcultures is also somewhat useful for this case study of an environmental group. There are many definitions of subcultures and it is almost impossible to state which is most accurate, but here Wolf members are considered to be people with a special interest who do not see themselves as outside the majority. It is thus possible to apply Mistrík's definition of a subculture, which claims that subcultures point out the shortcomings of the majority while still feeling part of the dominant culture (MISTRÍK 1999:4). The Wolf case fits this definition when its efforts to change the majority's attitude towards the environment are understood. Their espousal of different life values also indicates that Wolf members form something like a subculture, but what distinguishes them from real subcultures is the lack of a feeling of community life, which is so characteristic of subcultures. Many subcultural approaches and definitions are discussed in the collective monograph of McKay et al. (2009), in the Slovak context in Deák et al. (2010), and in the Czech context in Smolík (2010).

A final useful approach, though only from the anthropological point of view, is the application of Turner's theories of structure and anti-structure (TURNER 1978, 2004). This states that people sometimes leave their normal life and society (structure) and stay for certain time with another group of people with whom they usually do not share their time and space (anti-structure). What unites them for this time is a particular purpose (e.g. pilgrimage, demonstration, sport event and many others). It was difficult to decide whether to discuss these theories here, as it was not initially felt that they would be useful for the Slovakian case studies or for the Wolf case in particular. During the field research with Wolf, however, I spent many days in the forest with its members, almost completely isolated from other people. Debating various topics with them, a specific atmosphere was felt and observed that led me to a reconsideration of the value of Turner's theory as it might apply to the environment of conservationists isolated in nature. The common and collective interests of otherwise dissimilar people who have different educational backgrounds and experiences, jobs and come from contrasting social backgrounds made for a strong feeling of 'communitas' (anti-structure). Sometimes this feeling seemed to be a more compelling reason for joining Wolf and participating in its activities than Wolf's conservationist objectives themselves. The marginal influence of Turner's theory is noted, particularly within the MYPLACE context, and thus there is uncertain value in seeking to elevate it to the position of core theoretical approach. Nevertheless, given the experiences of fieldwork with Wolf it remains useful to continue to bear Turner's arguments in mind. 


\section{Methods}

In order to achieve the research objectives the methodological approach adopted here is one typical for social anthropology (or ethnology as it is more commonly called on the Continent). Thus, the fieldwork was more qualitative than quantitative, though there were some quantitative elements to the investigation, particularly the objective of obtaining interviews with 30 respondents, number given by MYPLACE leaders and their objectives. Nevertheless, the primary methodological orientation was ethnographic in approach, given the objective of understanding the nature of activity in Wolf as well as the values and understandings of its members.

The basic method of research was thus participant observation. Altogether, I participated in couple of events and approximately one month's worth of field research in the forests. Participation also took place in two summer camps, once in the field seminar GAIA - Our Home and a second in a reunion meeting on the occasion of the autumnal equinox and summer solstice. The final event I participated in took place in a village, and it was dedicated to the preparation of so-called information stands.

During these events, it was possible to participate in various kinds of activities (e.g. marking natural reserves, preparation of information stands) and which also provided opportunities for informal conversational interviews and pictures taking. Only a few interviews were recorded during these events for the simple reason that recording was both disruptive and impossible under the circumstances. These events take place only a few times a year and there are always many people who have not seen each other for a long time, so they want to enjoy and use the time they have well. Since one interview consumes about one hour of time, attempts to interview may have been regarded as a wasted of their time. In addition, it would have been very difficult to conduct and record a formal interview in the presence of many other people. Instead, a much more useful strategy was to form friendships and create a network of potential respondents. To this end, e-mail addresses and cell phone numbers were collected and later used to arrange more formal interviews.

During the period July - December 2012, I travelled across almost the entire country to record formal questionnaire-based interviews divided according to themes. Twenty-nine interviews were recorded, each on average one hour long, and one respondent wrote his answers to the questions because he did not want to be recorded. Three of the recorded interviews were undertaken via Skype, twice for the convenience of informants and once because weather conditions were so bad that it was not possible for me to travel. In total, 12 women and 18 men were interviewed, but this does not reflect the gender composition in Wolf membership. The fewer number of women was most likely a reflection of the fieldwork and sampling strategies since women are represented in Wolf in more or less 
equal numbers compared to men. The age range of informants was between seventeen and thirty years at the time of the interview, with thirteen of them younger than twenty-five. Field notes recorded in a fieldwork diary also complemented the recorded interviews.

When planning the field research, potential problems that might arise for any reason were considered. Fortunately, no ethical problems occurred, and only one respondent refused either to meet with me or fill out the questionnaire. On the contrary, the willingness of the young Wolf members to spend time answering questions was a pleasant surprise for me.

There was only one potentially very serious problem at the beginning of the study and that was uncertainty over the ability to find enough respondents in the requisite age range. To be honest, until the decision was taken by MYPLACE to raise the age limit for participants to 30 years old it was felt there would be serious trouble acquiring sufficient respondents.

As noted above, there were no significant ethical issues. There were no problems in asking people to participate in interviews, and there seemed no need to obtain formal consent to the study from the respondents. Wolf is not an extremist organisation, although there are people in Slovakia who consider them eco-terrorists. But because none of their activities violate the laws of the Slovak Republic, Wolf members are not afraid of persecution by the authorities. This is most likely one reason why they did not have any problem consenting to being interviewed. In addition, almost all the members of this organisation consider it and themselves to be radical in the strictest sense of the word. The word 'radical' is derived from the Latin word 'radix', meaning 'root'. In this light, Wolf's radicalism consists in going inside the problem to find a real solution to any issue. Wolf does not remain on the surface; on the contrary, it goes to the root of the problem.

In conclusion, the methods used were relevant to the objectives of the fieldwork, and they allowed the gathering of a significant amount of data. After more than a year of intensive contact with Wolf members, it was possible to establish very good relationships with many of them, including the leaders, which allowed me a better understanding of how this organisation functions. And, last but not least, I am now integrated into Wolf's communication network, and thus I am able to continue this investigation beyond the originally intended period of research associated with MYPLACE. 


\section{Key Findings}

At the beginning of this section it is necessary to describe the Wolf - Forest Protection Movemen in general terms. Wolf is an environmental organisation officially founded in 1993 as a non-governmental organisation (NGO) with the specific objective of ecological activism. It is no exaggeration to say that it is the most active environmental organisation in the country and the best known among the public as well. Two key reasons lead me to this conclusion. The first is the mass media's presentation of this organisation, which is based on the positive public response to Wolf's activities. Through these activities, Wolf drew a response considered to be worthy of media attention by journalists themselves. If there is even a single mention of an environmental issue in the mass media, it is almost always connected with Wolf. The second reason is my own experience acquired during the investigation. Asking Slovak people about the environmental organisations they knew, their answer, if they knew of any at all, was almost always the same - Wolf. This is, of course, closely related to media coverage.

Wolf's activism is aimed at conservation of forests in general, but specifically of socalled evolutionary forests and the natural processes occurring there. This particular and specific objective distinguishes this organisation from others. Most environmental groups are focused on very general, even global eco-problems such as water, soil and air pollution, the protection of endangered species of animals and plants, alternative ways of life in harmony with the environment, etc. In contrast, Wolf is focused solely on conservation of the forests, and its message is that only old and untouched forests are able to carry out all their functions. Only such a forest, for instance, is able to hold water and consequently to prevent floods. The opinion of one Wolf member speaks on behalf of the whole organisation:

"The subject of conservation and protection in those natural reserves which belong to Wolf or which are hired by Wolf is not any particular species of animal or plant but those processes, evolutionary processes, which are under way in those forests. The aim of Wolf is to preserve those natural forests or virgin forests because they have much bigger ecological stability than forests which have been substantially changed or influenced by man and his economic activity. Those forests fulfil their ecological functions better, there is higher biodiversity there and thus they guarantee soil protection and land protection against the floods much better. Wolf tries to convince the government that to manage forests less drastically is more effective than to invest billions in anti-flooding measures." (Jano) ${ }^{2}$

2 All the names of the respondents are fictive in order to keep the anonymity of my informants.

DOI: 10.1515/eas-2015-0010 C University of SS. Cyril and Methodius in Trnava. All rights reserved. 
Wolf members base these beliefs on the findings of natural scientists. In their opinion, global eco-problems are too general and too distant from topical and hot problems in Slovakia. But, as has been mentioned above, even though Wolf is often perceived by its opponents (mostly foresters, hunters, developers, and financial lobbies) as an eco-terrorist organisation, it acts completely within the parameters of the Slovak legal system. This means that Wolf members do not violate the laws of the country. On the contrary, they use the law for their own purposes, which is not always welcomed by their opponents.

The headquarters of this group is neither in the capital (Bratislava) as might be assumed, nor in any of the other moderate-sized Slovak towns. Because all Wolf's work can be done from any location and communicated to any other member via internet or telephone, and because there is a network of members throughout the country (including Bratislava) it is possible to address problems as they surface anywhere. The group's headquarters are in the small village of Tulčík in Eastern Slovakia, close to the town of Prešov. Wolf was founded in that region, in the Čergov Mountains specifically, and most of its key members are from there or live there now. Apart from the Tulčík headquarters there are two more offices, both in the East. One is in the small town of Snina, where one of the leaders lives, and the other in the remote village of Osadné, where Juraj Lukáč - the head chief of the organisation - lives.

\section{Structure of the organization}

Wolf has several hundred members across Slovakia. Therefore the organisation must be structured in accordance with regions what does not make it different from other organisations. What is different is the terminology used for the structure, which is borrowed from Native Americans. When asked why Wolf did not have a chairman, president, or whatever is usual in Slovakia, the reply was that because of the communist past they were allergic to the word 'chairman' and to all other communist terminology. That is why Juraj Lukáč is 'head chief' of the whole organisation, which is then divided into tribes named after Slovak mountain ranges. Together there are seven tribes at this time ${ }^{3}-$ the East Carpathian Mountains, Tatras, Pol'ana, Slanské Mountains, Little Carpathian Mountains, Strážov Mountains and Fatras. Every tribe has its own chief and functions as an autonomous unit within the organisation. The chiefs of each tribe form the Council of

It means in 2015 .

DOI: $10.1515 /$ eas-2015-0010

(c) University of SS. Cyril and Methodius in Trnava. All rights reserved. 
Elders, which discusses the most important issues. There are also the so-called Eternal Wolves, who have authority to deal with issues of internal dispute. Among the Eternal Wolves are the founding members of the organisation and those members who have been with the group for more than seven years and who are accepted and authorized by all current Eternal Wolves. Membership in this body is for life and Eternal Wolves can veto decision of Council of Elders if it is contrary to statutes of Wolf, however, their veto must be unanimous. In such a case the Council of Elders can discuss vetoed matter only after six months. To be an Eternal Wolf is a matter of honour, implying only personal authority, not authority conferred by the title. In fact, the personal authority of respected members in general cannot be denied. Even though Wolf has a formal structure, respect and appreciation are determined by the personal qualities of each member. This feature corresponds very much to the customs of Native Americans.

Wolf's structure is very free, formal, and democratic. No one has to obey anyone else because of the other's position or function within this formal structure. The most respected person is indubitably Juraj Lukáč, the founder and head chief of Wolf. As the highly respected, and appreciated person who created the organization, and defined its objectives and vision, his opinion carries the most weight in all discussions, and in the orientation of Wolf's activities. However, he is almost sixty years old (at least twenty years older than the majority of the members) which, on the one hand, contributes to his authority, but on the other poses the question of what will happen if he retires or falls ill. Some of the respondents did not know how to answer this question; some told me that there are capable people in Wolf who could step into his shoes; and some said that they purposely avoid this issue in their discussions. Here a couple of opinions are offered:

"So I cannot imagine it. Right now I do not see any successor of him who would manage what Juro does. It will crystallize step by step when it happens.” (Filo)

"This is the question which I have perceived during the last couple of last years because I can see that Juro is getting older. Since I have been a member of Wolf for the last eight years I can see that. I also talk about it with various people, not only with you. Some people think that Erik Baláž is brought up and educated by Juro step by step. I do not know if it is true. I do not see Erik that much. To tell the truth I do not know if there is such a person at this time which would be able to substitute for Juro. It is about the experience. Sure I do not see it like someone completely new would come and substitute for him. It must be someone who has already been in the structure of Wolf but who could be he/she... That person must also want it. So I do not know. And it is very interesting. I am curious how it will be. And I also worry about it. " (Kaya) 
"I am sure he is very busy with Wolf's matters but I think he still manages it and there are very many people in Wolf exactly who are such strong like him. Erik Baláz or Škorec or other ones. I would say they are the people of which Juro's equal successor will come. They know everything about all activities as Juro and other people who are engaged in them. So we would miss Juro as a person but I think he is replaceable and his retirement or death would not cause the end of Wolf or something like that." (Ondrej)

There are about 670 members in Wolf, but only one-tenth can be called full members. The rest are so called support members who pay membership subscriptions of 10 euros a year, the same as full member subscriptions. If a support member wants to become a full member s/he does not have to do anything special; s/he must only be more active in the organisation.

Apart from the division between full and support members, there are four more divisions in accordance with the frequency and intensity of each member's activism. The first one consists of core members. They are the most active members, devoting most of their time to the group, and eight of them are paid by the organisation. A second group is those members who co-operate regularly but not all the time, and who do not have regular responsibilities. The third group is made up of those members who were active at some time in the past and who are still available to sign petitions, for example. And finally, the last and largest group of members is the so-called non-active sympathizers. They support Wolf's ideas, but do not take part in its activities. In addition to these member groups, another 4500 supporters ${ }^{4}$ materially or financially contribute to Wolf.

Last but not least, it should be pointed out that most Wolf members are originally from urban areas even though many of them, including the head chief, have moved from towns to rural villages. Many of these migrants to rural areas moved as adults, under the influence of Wolf's ideology and a desire to be closer to the forests. It can be asserted that an urban membership base is quite typical for all social movements and subcultures. When compare Wolf with the Euro-Indians previously explored by me, and with neo-cottagers and the members of new religious movements studied by my colleagues, and when compared with other environmental organisations in Slovakia, an identical pattern of origin among the members of all these groups is found. The reason for this, it can be argued, is the difference between urban space and the countryside. Villagers grow up close to nature, and many of them see it as an everyday part of their lives. In contrast, urban people go to the

All of these numbers were provided to me during my fieldwork by the head chief's wife, who oversees the administration of the organization.

DOI: 10.1515/eas-2015-0010 C University of SS. Cyril and Methodius in Trnava. All rights reserved. 
mountains almost exclusively on weekends and holidays, which makes them more sensitive towards changes or any kind of commercial human intervention in their favourite places.

Another reason can be found in how busy villagers are in comparison with urban people. Villagers have their day jobs, but when they return home they must care for their houses, livestock, and garden or crops. There is, simply, always something to do around the house and land. And so they have no time to think about environmental problems, especially not if they use nature as a source of wood for selling or for heating, which is very common in Slovakia. Urban people do not have these concerns, and so they are free to address different issues, including environmental ones.

\section{Activities}

According to the web site (www.wolf.sk) Wolf's activities are concentrated in four basic programmes. The first is called Let Us Save Forests, and it is focused on the creation and recognition of natural reserves in evolutionary forests as well as on the protection of existing ones. This point has become very important since Prime Minister Robert Fico's left-wing party, supported by financial groups and real estate developers, took power after the election in 2012. This government has a very negative attitude towards environmental issues in general and Wolf in particular.

The second programme bears the name Let Us Save Predators, and it is focused on the protection of large predators in general (wolf, bear, lynx, golden eagle, Ural owl, etc.) through conservation of their natural habitats and through the enactment of protective legislation. Large predators are considered not only a natural part of the environment but also the keepers of balance in nature. This goal, of course, finds obstinate opponents among hunters, whose goal is the hunting of the same large predators, or, at least, to hunt the game, which is also hunted by large predators, thus creating not wished competition.

The third programme is focused on education, and it is named GAIA - Our Home. It is a nine-day-long outdoor seminar on evolutionary forests which takes place three times a year (May, June, September) in an evolutionary forest environment. The participants spend their time camping without fire or cooking, under all weather conditions. The aim is to have the participants experience nature more fully, but it is also aimed at education. Every day, a specialist in some particular discipline (botany, zoology, ornithology, etc.) comes to teach the participants.

The last programme is called ABIES (the Latin name for fir tree) and it is the name of Wolf's publishing house, which publishes eco-literature. 
These four programs are supported by various activities. The most visible and most famous one consists of buying forests and declaring them private nature reserves belonging to the organisation. The goal of this activity is to create forest zones where no human intervention is allowed, and only nature and not people will manage them. There is a custom in Slovakia that natural reserves are declared because some endangered species of animals or plants live there. Then, if this condition changes, there is no reason to protect the area any more. Apart from that, the authorities have always granted exceptions so that special interest groups could intervene in protected areas (e.g., for logging) even though all the nature reserves are officially declared highly protected areas without any human intervention.

In contrast, the forests belonging to Wolf are maintained strictly without intervention, and the unique objective of this conservation is the restoration of natural processes as a whole. Wolf owns two reserves, and both were declared on the same day - April 1st 2004 after several years of fighting against bureaucracy and authorities at all levels. Even though both were declared on the very same day, the so-called Wolf Reserve (Vlčia) in the Čergov Mountains in Eastern Slovakia was the first forest Wolf acquired (in 1998) as well as the first put through the process of private reserve declaration. The Wolf Reserve is precedential because it is the first private nature reserve anywhere in Central Europe. The second is called the Lynx Reserve (Rysia) and it is located in the Strážov Mountains in Western Slovakia. Neither is very large; the Wolf Reserve is 21.24 ha and the Lynx Reserve is 30.49 ha. But Wolf has already bought another 40 ha area adjacent to the Wolf Reserve which is not yet part of the reserve ${ }^{5}$. Apart from these two reserves owned by Wolf, Wolf has rented a part of the so-called Suchá Valley in the Tatras National Park, in which it has prohibited all logging. The valley was rented in 2002 for 40 years, and thus its protection is guaranteed. As well as declaring private reserves, Wolf develops projects to extend existing state reserves and to declare new ones. These projects have been successful in several cases, for instance in Udava and Bisce, both in Eastern Slovakia.

Another important and substantial issue that was initiated and developed by Wolf is the Environment Conservation Bill, which was in preparation for two years before 2011. The Bill was prepared in collaboration with lawyers and natural scientists from Slovak universities and scientific institutes. It requires that $10 \%$ of all Slovak forests $(5 \%$ of the whole country) be declared highly protected areas with no commercial, economic, or hunting activities. The Bill was introduced to Parliament in 2011, but failed to pass because

$5 \quad$ It means in 2015

DOI: $10.1515 /$ eas-2015-0010

(c) University of SS. Cyril and Methodius in Trnava. All rights reserved. 
of the sudden collapse of the centre-right government of Iveta Radičová, which supported it. Robert Fico's government, of course, has not concerned itself with this Bill; on the contrary, it has introduced its own bill, which significantly reduces the extent and the number of existing natural reserves, and so it is possible that Wolf will soon have serious problems keeping its three reserves at all. The original Bill is ready to be introduced again, but not before the next election, which will take place in 2016.

Various kinds of protests are also a part of Wolf's activism. It regularly organises petition drives, and it has resorted to a more extreme form of protest - a blockade - three times so far. The first occurred in 1996 in the Slánske Mountains in Eastern Slovakia, and the second in 1998 in the Pol'ana Mountains in Central Slovakia, when foresters wanted to cut down ancient forests. This blockade was so successful that it led one married couple to donate more than 30 ha of forest in the Strážov Mountains to the group. As readers have surely guessed, this forest later became the Lynx Reserve. The third blockade in 2010 was even more serious, and it attracted much more public attention. Wolf decided to blockade the Tichá and Kôprová Valleys in the Tatras National Park, which foresters had targeted for logging because of the devastating windstorm that struck the Tatras in November 2004. The Tichá and Kôprová Valleys form the very core of the park, and it was not possible to practice any logging there without an official exception, which could only be granted by the County Council of the Environment in the Capital of the District (the District Council), by the County Council of the Environment, or by the Ministry of the Environment of the Slovak Republic ${ }^{6}$. The exception was granted by the Ministry in 2007 during the first Robert Fico's government, and thus both valleys were sentenced to the destiny already suffered by the rest of the area affected by the windstorm. Wolf declared both valleys areas protected by the citizens of the Slovak Republic, and the massive attention of the mass media and public opinion, which looked with favour on the side of Wolf, stopped the logging. In 2010, a tent-camping protest was organised in Bratislava as a part of the plan to protect both valleys. The final decision of the Ministry came down in 2012, and both valleys were left untouched by human intervention. Some members of Wolf who participated in the blockade were injured by policemen or unsuccessfully prosecuted in court.

Wolf has also participated in judicial proceedings against violations of the existing Environment Conservation Bill, which happen quite often in Slovakia. The poaching of large predators and illegal logging in reserves and parks represent the most visible and most

$6 \quad$ Statute Book of Slovak Republic, Act No. 543/2002.

DOI: 10.1515/eas-2015-0010 C University of SS. Cyril and Methodius in Trnava. All rights reserved. 
known cases of such violations of the law. And last but not least, because of Wolf's intervention in the Court of Justice of the European Union, in 2010 the Slovak Parliament had to enact a law allowing NGOs to participate in administrative proceedings.

Wolf members are also engaged in educational activities consisting of lectures about nature conservation and various environmental issues at schools and in museums and libraries, etc. They believe it is necessary both to educate children and the public in general and to educate themselves in order to be ready to debate the issues with their opponents if necessary. These debates happen very often during the so-called information stands, which are organised in April and October in Slovak towns and in the summer at music festivals, including at the biggest festival in Slovakia, Pohoda, which takes place in Trenčín in Western Slovakia. Members need to be well informed about environmental issues as well as about forestry and legislation, etc., because many people ask them many questions at these events, and foresters and hunters often approach them as well. Apart from that, the information stands serve as a way to raise funds, get signatures on petitions, and inform the public about the organisation.

Members of Wolf meet each other on many occasions, but since they live in all regions of the country, it is often not possible to see each other very often, and so they organise four reunions a year for members only. These reunions always take place in the forest, usually (but not always) in one of Wolf's three reserves. The dates of the reunions correspond to the natural cycle, meaning they are organised on the weekends closest to the solstices and equinoxes. The most important is the winter solstice, because it is a time to look back on the ending year and to make plans for the new one. Another very special reunion, summer camp, which takes place at the beginning of August, or at the end of July and the beginning of August, is open to anyone (not only to members of Wolf) with an interest in nature conservation. Since it is dedicated to work, mostly in the form of marking private or state reserves or newly acquired forest plots, the place chosen for summer camp always depends on current need. My participation took place in the camps dedicated to the marking of newly acquired plots in the Čergov Mountains close to the Wolf Reserve (2012) as well as of an existing state reserve in the Busov Mountains (2013). Since summer camp is open to the public, it also serves as a very convenient tool for the recruitment of new members.

\section{Financing}

As an NGO, Wolf is not a profit-making organisation. Instead, all its financing comes from sponsors and membership subscriptions. As already mentioned, a subscription costs 10 euros a year, which does not yield enough to support the group. Given that a single hectare 
of forest costs 3,000 euros (not including other expenses such as the salaries of some members, and costs for lawyer or geodesist) it is clear that membership subscriptions cannot cover all Wolf's expenses. Therefore, the organisation depends on sponsorship. Because Wolf is very well established among the public after 20 years of successful existence, there are many people in Slovakia who support it financially or materially, through donations, etc. But Wolf has strict rules about the sources of its donations. The group only accepts money from individual citizens and not from corporations, the government, or politicians who would use it for their PR. Most of their money comes from the $2 \%$ of taxes which anyone can donate to any non-profit organisation.

To raise additional funds, Wolf also invented a programme called The Seventy-Seven Crown Banknote, before Slovakia adopted the euro as its currency. This means that anyone can create a standing bank order to donate at least 77 (former) Slovak crowns a month (about $€ 2.60$ ) to the organisation. In return, the donor obtains a 'banknote' in the amount of 77 crowns issued by the fictional Wolf Bank. Another programme invented by the organisation is called Buy Your Own Tree. A 50-euro donation to this programme will be used only to purchase more forest land, mostly in the vicinity of the Wolf Reserve, in order to enlarge it.

Apart from these four basic fundraising methods, Wolf gains money in the form of occasional financial or material donations, from contributions collected at the information stands, and very occasionally in the form of grants. Thus, the organisation has gained complete financial independence. In other words, it does not owe anything to anyone, it does not depend on state subvention, and it does not have to obey officials or political organisations such as the State Conservation of Nature (Štátna ochrana prírody - ŠOP). All the accounts are available on Wolf's website and the head chief told me that Wolf's budget is about 80,000 euros a year, much more than any other non-state conservationist organisation in the country.

\section{Wolf's Politics}

Wolf is a completely apolitical organisation but, of course, its members have their own political attitudes and opinions. The overwhelming majority of the members are right-wing oriented, a consequence of the two Robert Fico's governments as described above. This orientation is not about their social feelings or capitalist/anti-capitalist attitudes, but about the attitude of the politicians and political parties towards nature conservation, and about their willingness to negotiate with conservationists. Many members told me it was possible to negotiate and co-operate with right-wing governments but not with left-wing ones. That is why Wolf members vote for right-wing parties, or, rather, for particular candidates of 
these parties, and almost never for left-wing ones. They consider it very important to participate in elections, because as they say, voter passivity is convenient for left-wing politicians and opportunists. The opinion about left-wing parties is very clearly illustrated with the following statement:

"Fico has healed me completely from any kind of left-wing orientation. My opinion is that it's good if the state is governed by someone who understands money... economist. Fico is the lawyer and it is the worst what can be when a layer controls the state. I cannot say I am right-orientated, I prefer to say I am liberal. According to Wolf the situation is quite paradoxical because conservationist organisations are usually left-wing orientated as people say in general. Wolf not. But me, personally, I do not rely on anybody and my political opinions are created by myself. ” (Parafín)

Because Wolf must negotiate and co-operate with politicians and state officials on all levels, from regional to state governments and up to Parliament, and because of its involvement in the creation, change and enforcement of environmental laws, and also because it declares nature preserves, it can be said that although it is an apolitical organisation, it does not operate outside politics. Head chief Juraj Lukáč knows almost all the politicians personally because he must negotiate with them. A very charismatic person who is well-known by the public, representatives of right-wing parties have asked him many times to be their candidate for parliament. Especially before the election in 2012, a party called Ordinary People - Independent People (Obyčajní l'udia - nezávislé osobnosti OL-NO) - was particularly insistent that he be its candidate. He refused because even though he could influence many issues as a Member of Parliament, he did not want Wolf to be connected with any political party. As can be seen, Wolf is very active in the political arena, but its activism cannot be considered to be political at all which is illustrated by the following statement:

"I cannot say that Wolf is engaged in politics. Wolf must cooperate with any particular government because it has an influence. It does not matter if it is left-wing or right-wing government. We must negotiate with it and assert our opinions. If Wolf started to profile itself politically it would disgust some opponents but it would close some politician's doors as well. We try to negotiate assertively with anyone.” (Matúš)

\section{Young people in Wolf}

Young people form an important part of the group, but Wolf is not a youth organisation and it does not have an independent or semi-independent youth unit, as can be found (and seen many times) in many political or nationalist organisations. Even so, young people are very important to the functioning of Wolf. This is true because young people in general are the 
most active part of society and they are more ready to protest than older people, who have families and thus different priorities. Young people have always been more revolutionary and more rebellious against authorities and established systems than people who must support their families. That is the reason young people do most of the volunteer work in Wolf, which is essential for Wolf's activism.

This may be the place to ask why young people find Wolf attractive when there are so many other ways to spend their free time. The first answer lies in their love of nature. This ordinarily comes from their family backgrounds, and it is closely related to their parents and education. If young people do not have this background, the probability that they will join an organisation like Wolf is very low. There are only a few cases when it happened without this family background, and in those cases, their reasons for joining Wolf lay in their desire for activism in general. But even if a love of nature is one of the main reasons for joining this group, it still does not explain Wolf's appeal because, as mentioned above, there are several other environmental and conservationist organisations in the country, and young people can choose which one to join. So why is Wolf so popular among the young? It can be argued that Wolf is attractive because it is radical in the strict sense of the word, which is derived, as I mentioned above, from the Latin word 'radix', which means 'root'. It must be repeated that it is not an extremist organisation, but radical in its unyielding attitude towards authorities and its uncompromising advocacy of its vision and objectives. At the same time, Wolf's radicalism means it approaches environmental problems by trying to penetrate to the core issue rather than addressing the outward symptoms. For example, Wolf would not find it necessary to clean up the garbage and litter carelessly discarded in forests. Instead, it believes it is necessary to teach people how that kind of behaviour harms the forest, and convince them not to do it. This is just a very simple example. However, it explains the radicalism of the Wolf in the words of its members as it can be illustrated with the following examples:

"Yes, of course. I consider Wolf to be radical organisation since I have understood what the word 'radix' means. And I like it very much. If radical, 'radix', roots, it is necessary to reach the roots of the matters. It should be like that in life, in everything. I see it as a good way and as such it is our philosophy." (Anton)

"According to my opinion it is radical because it has ideas and visions and some actions of Wolf have never been here before. That know-how of this organisation is unique and actually radical by this manner. But not in bad meaning of the word." (Samuel) 
A second reason youth is attracted to this organisation lies in the success of its activities. As far as it is known, Wolf has been very successful in its efforts, which gives meaning to what it does.

Concerning the level of education of Wolf members, there are many young members who are university students or who already have university degrees, and many of them studied the natural sciences such as geography, geology, environmentalism, forest ecology, etc. Other members hold degrees in the social sciences or humanities (in languages, for example). It is true that members of environmental organisations are usually but not always well-educated and middle-class people, as demonstrated by Pickvance in relation to environmental movements in Russia and Hungary. Leaders, especially, tend to be highly educated (PICKVANCE 1997:41). It can be confirmed that the same situation exists in Wolf, although not all of its members or even all of its leaders have university degrees.

Even though Wolf has a formal structure as described above, it is also a very democratic organisation, without a real hierarchy. Only the personal authority of experienced members determines the position within the organisation. No formal discipline is imposed, and relationships among the members are based on friendship, respect, and a common goal. Since no real hierarchy exists, the generation gap also does not exist. It is very attractive for young people that there are no differences among the members because of their ages. Anyone can say anything to anyone else, and all opinions are welcome and open to discussion, even though in practice the younger members often listen to the older because they are more experienced. More important than actual age, though, is how many years someone has been a member of the group, because many quite experienced Wolf members are still chronologically very young.

The absence of a generation gap or hierarchy is also expressed in the member's way of addressing each other, which is always on a first-name basis, without regard to age. One member described to me this situation:

"When I came for the first time to the an Wolf's event, I was about 19, 20 years old, all of us were addressing each other on a first-name basis, including to Juro Lukáč, and we were talking to each other as equals. I think it is not so common in other organisations. So in my opinion the generation gaps within the Wolf are minimal. " (Milan)

Another said that:

"Yes, I like it. Young or old, we address each other by first names. We are one community and we meet each other even outside of Wolf's matters and events. Of, course, there is a hierarchy. There are chiefs who are the people who act in the public. Juro Lukáč as a head chief is almost like an icon of Wolf which has charisma but the relationships are more or 
less equal. It does not matter if someone is chief or not. To be chief is manifested in relation with the public, outside of the organisation. But inside of that every single full member or support member has a possibility to speak to everybody and to solve the problems. And I have not met openly demonstrated superiority of Lukáč or any one yet what is super." (Braňo)

And again:

"Since the beginning it has been one of the things which I like very much in Wolf. That there is practically equal conversation there. For instance we address each other on firstname basis. All of us. Since the first day we do it with 50 years old members, Juro is 50. And surely, those young people, if they have a sense they understand that those older ones are more experienced and thus they behave by this manner. They take into account that those older ones are more experienced so they ask them more and they do not look like masters at the very beginning. I do not feel my age as limiting factor.” (Kaya)

Such character of the relationships within the group gives young Wolf members enough space for self-realization, which has always been appreciated by the informants. And all of these features together give them a feeling of pride as members of this organisation.

The MYPLACE project researched youth political activism and civic engagement, and in light of these criteria, Wolf does not sit to easily within this. Members in general and young members especially considered themselves to be apolitical, as is the entire organisation. This does not mean that they are not active, but their activism is based on civic engagement and not at all on political involvement. This statement of one of the respondents serves as an example:

"I think that I do not know anything about [politics] and sometimes I am glad if someone teaches me something about it. If someone I trust knows something about it I am glad when he/she explains some matters to me. But I think I know very little about it and I do not have any political background. Sometimes I do mind it but I have not made the effort to improve it." (Kaya)

\section{Conclusions}

After more than a year of research, a lot has been learnt about the Wolf - Forest Protection Movement, but there is much more to learn. There is always a way to improve research and the state of knowledge, but this was a successful case study. The number of requisite interviews was undertaken and fieldwork took place observing several events and activities organised by Wolf. Since the majority of these events and activities are annual events, there 
remains the possibility of taking part in them in the future. A good understanding of the organisation was developed: its functions, membership and the participation of young people. It was also discovered that the activism of Wolf members is far from political or extremist activism and that the organisation must co-operate with politicians at different levels of government, with state administrators, and with other environmental organisations, although co-operation with these last depends on whether their objectives are compatible with Wolf's. For instance, Wolf does not co-operate with Greenpeace Slovakia because it is ideologically a completely different organisation.

Concerning the activism and civic engagement of Wolf's young members, it was discovered that they are very actively engaged in public affairs only in relation to environmental issues and the conservation of the forests and large predators. Wolf is a very successful organisation, highly attractive to young people who want to do something meaningful. Without the success of their activities, it would be very hard for the organisation to attract so many (not only) young people.

As Pickvance points out, the survival of any individual movement depends on the success of the wider movements within the society in which it operates and beyond. Success depends on the political situation (democracy vs. authoritativeness) and the amount of resources (PICKVANCE 1997:45). Even though democracy is still very young and not as developed as many in Slovakia would like it to be, it is possible to predict that Wolf will not have any problems surviving both because of the more or less favourable and tolerant situation in the country, and because it has been very successful in what it does. And, of course, because it has set up fundraising systems that supply it with sufficient resources to accomplish its goals. It is also significant that Wolf is not an exclusive club. It is open to anyone who is interested in nature conservation and who identifies him/herself with the vision and objectives of the organisation.

Young people are important to any social and civic movement, environmental or otherwise, and Wolf is no exception. Young people represent the future of every organisation and movement, and it is necessary to influence them in accordance with the principles of each particular group. Apart from this, they do most of the voluntary work, which is one of the most important activities characterising all social and civic movements. Youth are usually enthusiastic and ready to broadcast their beliefs and attitudes to their elders and society as a whole. And last but not least, young people have time for volunteer activities. Zani and Cicognani state that the motivation for such participation lies either in egocentric interests (for instance personal well-being or self-esteem) or altruistic interests (collective well-being) (ZANI and CICOGNANI 2010:84). Even though the first group of interests seems to be viewed negatively, there is another interpretation. On the contrary, the satisfying of one's own desires very often contributes to the fulfilment of common goals 
and it is logical that collective efforts must also satisfy the individual desires of their participants. The research revealed this attitude among all respondents. The question concerning whether they feel personal satisfaction when they do something for Wolf was always answered positively, with the explanation that every group success is personally satisfying because they see the positive results of their own efforts, and that gives meaning to what they do and to their volunteerism.

Volunteerism as a substantial part of any activism has six functions - a values function (concern for the welfare of others), a knowledge function (an opportunity to learn, understand, practice and apply skills and abilities), a career function (a chance to improve job prospects), a social function (due to normative or social pressures), a protective function (a reduction in feelings of guilt about being more fortunate than others) and an esteem function (the enhancement of self-esteem, self-confidence and self-improvement) (ZANI and CICOGNANI 2010:84-85). It is possible to agree with them only if it is accepted that not all six functions can be applied to each case of volunteerism. That is to say the career, social, or protective functions of volunteerism were not found among the Wolf members. It's possible the protective function could be applied in relation to nature and with the future protection of the people from floods and droughts, but this idea does not comply with the definition.

As mentioned in the Introduction, a (post) subcultural approach and Turner's theory could be applied to the study of Wolf as well. But because these approaches seem of only marginal value here, especially Turner's theory, they will not be elaborated upon here. The Wolf as an organisation does not lend itself to these approaches.

In 2013 Wolf - Forest Protection Movement was celebrating its twentieth anniversary since its founding as an NGO. This means that it is not a fad, or a flash in the pan. If it is taken into consideration that it has existed since the late 1970s as part of SZOPK (not independently and, of course, not as an NGO), it is an organisation with extensive experience in the field of nature conservation. And from this point of view, its activism must be considered. As it has been pointed out, Wolf is an apolitical organisation with no political aspirations and it is in this manner the activism of its young members must be judged. Because of the lack of political activism, it is not easy to categorize this group within the range of MYPLACE project ${ }^{7}$, and, as the only environmentally-oriented case, it stands outside the other groups studied by the project participants. But Wolf provides a valid case study because it is characterised by strong civic activism represented by public

7 To see more consult above mentioned website.

DOI: 10.1515/eas-2015-0010

(c) University of SS. Cyril and Methodius in Trnava. All rights reserved. 
action, by legislative activities, and by co-operation and negotiation with politicians and state officials on all levels.

\section{References}

DEÁK, D. et al. (2010). Alternatíva, životný štýl, identita? Niekol'ko pohladov na súčasnú slovenskú spoločnost', Magma: Čadca.

McKAY, G. et al. (eds.) (2009). Subcultures and New Religious Movements in Russia and East-Central Europe, Peter Lang: Oxford.

MISTRÍK, E. (1999). 'Dominanta a alternative. In R. Džambazovič and R. Kloboucký (eds.). Súčasné subkultúry mládeže. Zborník príspevkov zo seminára Sekcie sociologickej teórie Slovenskej sociologickej spoločnosti pri SAV uskutočneného 21. októbra 1998. Bratislava: Slovenská sociologická spoločnost' pri SAV, pp.4-7.

PICKVANCE, K. (1997). 'Social Movements in Hungary and Russia: The Case of Environmental Movements.' European Sociological Review, 13(1): 35-54

SMOLÍK, J. (2010). Subkultúry mládeže. Uvedení do problematiky, Grada: Praha.

TURNER, V. and TURNER E. (1978). Image and Pilgrimage in Christian Culture. Anthropological Perspectives, Columbia University Press: New York.

ZANI, B. and CICOGNANI, E. (2010). 'Forms and Motives for Adolescent's (non)Participation.' Forum, 21(5): 83-89.

\section{Websites}

www.wolf.sk

www.zakonypreludi.sk

http://www.fp7-myplace.eu 